\title{
CATCH ESTIMATION AND SIZE DISTRIBUTION OF BILLFISHES LANDED IN PORT OF BENOA, BALI
}

\author{
Bram Setyadji, Jumariadi and Budi Nugraha \\ Research Institute for Tuna Fisheries Benoa \\ Received August 2-2011; Received in revised form May 29-2012; Accepted June 6-2012 \\ email: bram.setyadji@gmail.com
}

\begin{abstract}
Billfishes are generally considered as by-product in tuna long line fisheries that have high economic value in the market. By far, the information about Indian Ocean billfish biology and fisheries especially in Indonesia is very limited. This research aimed to elucidate the estimation of production and size distribution of billfishes landed in port of Benoa during 2010 (February - December) through daily observation at the processing plants. The result showed that the landings dominated by Swordfish (Xiphias gladius) $54.9 \%$, Blue marlin (Makaira mazara) $17.8 \%$ and Black marlin (Makaira indica) $13.0 \%$ respectively, followed by small amount of striped marlin (Tetrapturus audax), sailfish (Istiophorus platypterus), and shortbil spearfish (Tetrapturus Angustirostris). Generally the individual size of billfishes range between 68 and $206 \mathrm{~cm}$ (PFL), and showing negative allometric pattern except on swordfish that was isometric. Most of the billfish landed haven't reached their first sexual maturity.
\end{abstract}

\section{KEYWORDS: Catch, species composition, billfish, length and weight}

\section{INTRODUCTION}

The term "Billfishes" has been globally accepted and referred to the large pelagic fishes of the families of Xiphiidae and Istiophoridae. The fishes characterized by the prolongation of the upper jaw, much beyond its lower, into a long rostrum which is flat and sword-like (swordfish) or rounded and spearlike (sailfishes, spearfishes, and marlins) (Nakamura, 1985). Billfishes are primarily oceanic, epipelagic species inhabiting the coastal and offshore waters of all tropical and subtropical seas (Pepperell \& Grewe, 1999 ) they usually swim to the water layers above the thermocline, but some of them may occur at greater depths (up to $915 \mathrm{~m}$ ) (Conamar, 2008).

The catch of billfish is generally considered as one of the tuna long line fisheries by-product (secondary catch which have an economic value), and it is often poorly recorded, being lumped together in to single category, misidentified or the fish is discarded (Campbell et al., 1998). The contribution of billfishes to the fishery is significant, and the catch has increased considerably over the years highlighting their importance in the large pelagic offshore fishery in Indonesia. The recorded catch from Indonesian vessels increased to over $400,000 \mathrm{MT}$ in 2007 by all fleets in the Indian Ocean (Mahiswara \& Prisantoso, 2009), that mainly landed in Port of Benoa, Bali and two other main fishing ports, Cilacap and Palabuhan Ratu.

Knowledge of Indian Ocean billfish biology and fisheries especially in Indonesia, and the status of billfish species remains unclear due to lack of data and information of the fishery. This research aimed to elucidate the estimation of production and size distribution of billfishes landed in port of Benoa, Bali.

\section{MATERIALS AND METHODS}

The data analyzed were part of the result of daily observation at processing plants in Port of Benoa, Bali conducted from February to December 2010, following the IOTC protocol (IOTC, 2002). The data taken covers Pectoral Fork Length (PFL) (the frozen billfishes are usually came with no head and fins; in centimeters) (Figure 1), HDD Weight (dressed carcasses with heads and fins off and tail present; in kilogram), name and number of vessels, with notice: every samples were weighted but weren't always measure its length due to difficulty and limitation at the processing plant. Species identification based on Nakamura (1985); Pepperell \& Grewe (1999).

Calculation of the total catch based on following formula (IOTC, 2002):

$$
\mathrm{CM}=\mathrm{LM}{ }^{*} \mathrm{AVM} \text {. }
$$

Where:

$\mathrm{CM}$ : Total catch per month (in Ton)

LM : Total landing per month (in Ton)

AVM : Average catches per month (Catches sample/ Landing sample)

These data are tabulated on spreadsheets in the form of excel ${ }^{\text {tw }}$ format by strata - year, month, and species. 


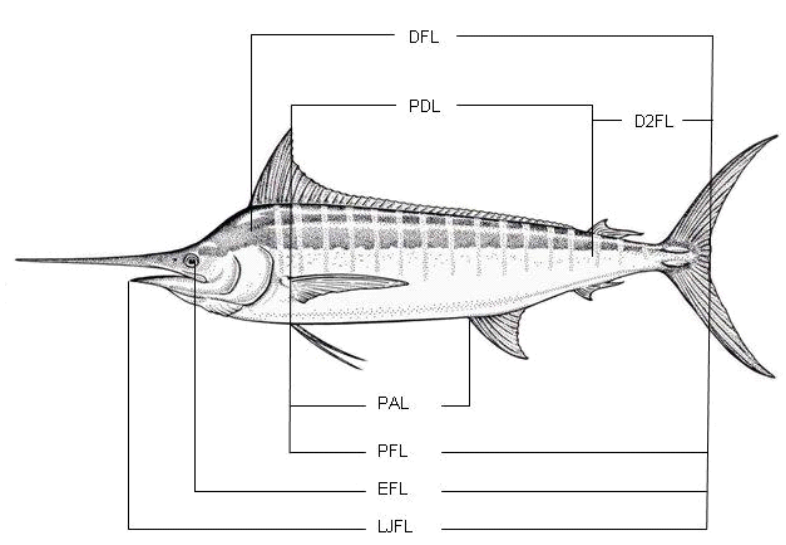

Figure 1. Type of measurement used for billfish Remarks:

PAL : Pectoral Anal Length

PFL : Pectoral Fork Length

EFL : Eye-Fork Length

LJFL : Lower Jaw-Fork Length

DFL : Dorsal-Fork Length

PDL : Pectoral-Dorsal Length

D2FL : Second Dorsal Fork Length

Source: Poisson \& Paquet (2001) after IOTC (2005)

\section{RESULTS AND DISCUSSION}

\section{Catch estimation}

There were six identified species of billfishes (from 12 known worldwide; Froese \& Pauly (2011) ) which landed in Port of Benoa. One species belong to the family Xiphiidae (Xiphias gladius) while the others are from family Istiophoridae (genus Istiophorus: Istiophorus platypterus; genus Tetrapturus: Tetrapturus audax, Tetrapturus angustirostris; genus Makaira: Makaira mazara, Makaira indica).

Total of billfishes sampled during February to December 2010 at the processing plant in Port of Benoa showed that the catch was dominated by Swordfish (Xiphias gladius) $54.9 \%$, Blue marlin (Makaira mazara) $17.8 \%$ and Black marlin (Makaira indica) $13.0 \%$ respectively and then followed by small group of Striped marlin (Tetrapturus audax), Sailfish (Istiophorus platypterus) and Shortbill spearfish (Tetrapturus angustirostris) (Figure 2).

Monthly catch estimation of billfishes landed in Port of Benoa showed that total landing of swordfish likely fluctuated every month but reached its highest in June for about 137.927,21 ton and dominated the total catch throughout the year. Blue marlin and black marlin followed with different pattern which occur mostly in March - April and October - November. Striped marlin occurred mostly in October - November but in less abundance.

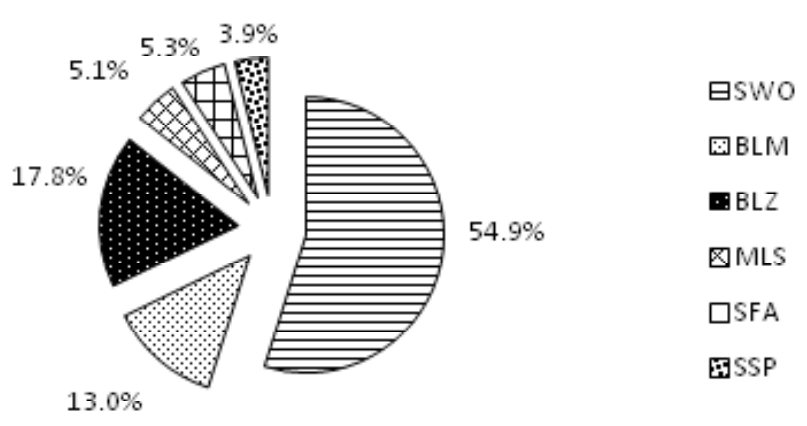

Figure 2. Total Billfishes landed in Port of Benoa during February-December 2010.

Remarks : SWO (Swordfish; Xiphias gladius), BLM (Black marlin; Makaira indica), BLZ (Blue marlin; Makaira mazara), MLS (Striped marlin; Tetrapturus audax), SFA (Sailfish; Istiophorus platypterus), SSP (Shortbill spearfish; Tetrapturus angustirostris)

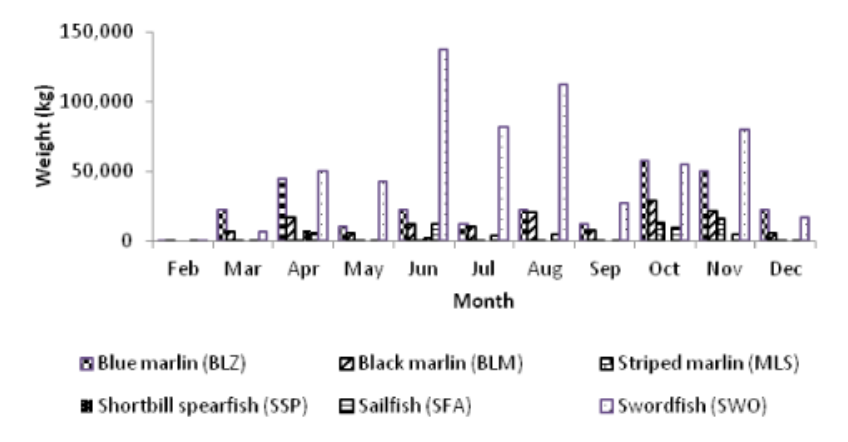

Figure 3. Catch estimation of billfishes landed in Port of Benoa during February-December 2010.

According to Indonesian Tuna Long line Association (ATLI) during 2005-2009 the production of billfishes landed in Port of Benoa had increased which Swordfish was the common commodity (up to more than 3,000 ton in 2008 and 2009) followed by group of marlins and sailfish (about 1,500 ton in 2009) (Figure 4). This result seemed to follow the pattern of the billfishes production in Indian Ocean waters of Indonesia (Western Sumatera, Southern Java and Lesser Sunda) for which it fluctuated in $2004-2007$ period but still showed the same catch composition in which swordfish was the common species, while striped marlins showed in small quantities (Mahiswara \& Prisantoso, 1999) (Fig. 5) 


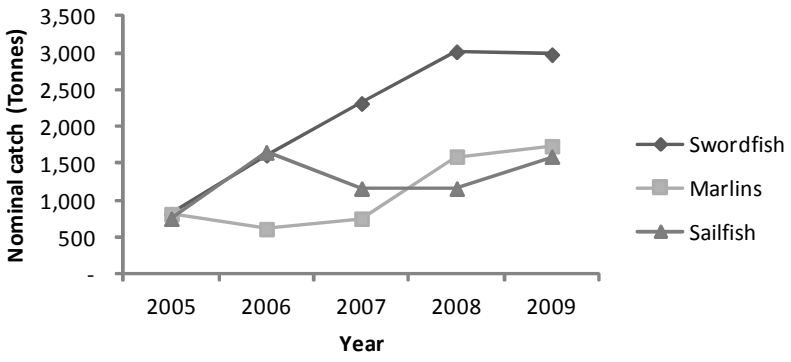

Figure 4. Nominal catch of Billfishes landed in Port of Benoa during 2005-2009.

Source : Indonesian Tuna Longline Association (ATLI)

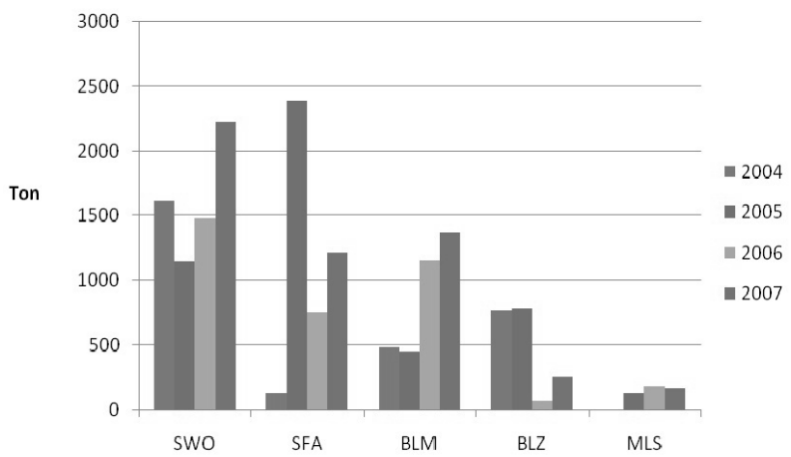

Figure 5. Billfish production from Indian Ocean Waters of Indonesia 2004 - 2007.

Source : Mahiswara \& Prisantoso (2009)

\section{Size distribution}

From sampling activities carried out from February to December 2010, generally the individual size of billfishes range between 68 and $206 \mathrm{~cm}$ (PFL). The swordfish landed sized 68-197 cm (PFL) (Fig. 6) which relatively similar with Poisson \& Fauvel (2009) report in southwestern Indian Ocean and Sun et al., (2005) in the waters around Taiwan, regardless its sex. Black marlin and blue marlin ranged from 108 to $206 \mathrm{~cm}$ (PFL). Maldeniya et al., (1999) reported, in Sri Lanka waters the blue marlin catch ranged from 110 to $270(\mathrm{FL})$, the size range noted of black marlin caught in Indian Ocean by Japanese long liners during 1960s ranged between 121 and 260 body length (LJFL), which also mentioned for the maximum recorded total length of black marlin is $448 \mathrm{~cm}$ and maximum recorded weight was $708 \mathrm{~kg}$ (game fishing record, caught off Peru in 1953) (Pepperell, 2000). Size range for striped marlin was from 95 to $158 \mathrm{~cm}$ $(\mathrm{PFL})$ as for information in equatorial west Indian Ocean ranged between 120 and $190 \mathrm{~cm}$ (Eye ForkLength; EFL) (Merret, 1968 (after Ueyanagi \& Wares, 1975)), while sailfish ranged from 114 to $175 \mathrm{~cm}$ (PFL) which is bigger compared to study by Hoolihan (2006) from Arabian Gulf but still within range reported by
Ganga et al., (2008) in Indian coast. There were also three individuals of shortbill spearfish measured that ranged 124 to $127 \mathrm{~cm}$ (PFL), Novianto et al., (2010) reported the size of shortbill spearfish caught in Indian Ocean from September - December 2008 ranged 135 $-175 \mathrm{~cm}$ (LJFL).
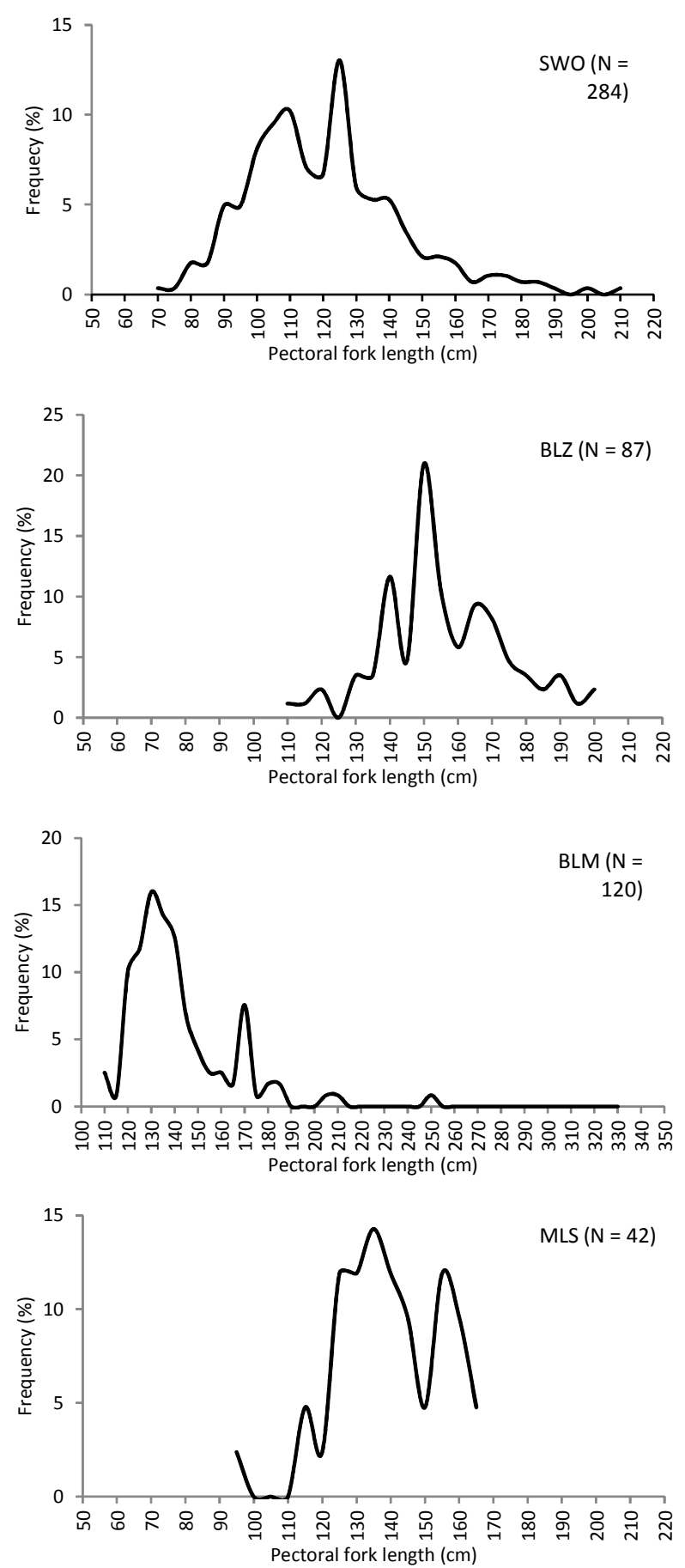

Figure 6. Pectoral Fork-Length frequency distribution of dominant billfishes landed in Port of Benoa, February - December 2010 
In artisanal and industrial tuna fisheries, tuna, billfish, tuna-like species and by-catch species are processed in many different ways and landed in different states (round, gilled and gutted, headed etc) (IOTC, 2005). Measurements of actual size (length and weight) are recorded before processing when observers are onboard fishing vessels or when fish are landed whole. Given that processing is common practice, being able to convert different measures of dressed and undressed fish to whole fish is essential. Almost all billfishes came with no head, gills, fins and eviscerated. Fish can also be frozen at $-20^{\circ} \mathrm{C}$ (for the European market), or at $-50^{\circ} \mathrm{C}$ for the tuna destined for the Japanese sashimi market and the loins for the European market (Poisson \& Taquet, 2000). The weights of billfishes are likely grouped between 30 and $50 \mathrm{~kg}$ (HDD) with the lowest about $1 \mathrm{~kg}$ and maximum up to $206 \mathrm{~kg}$ (Fig. 7). The landing record represents that most of the catch are slightly lower compared to reports in southeastern Pacific (Vega et al. 2009).
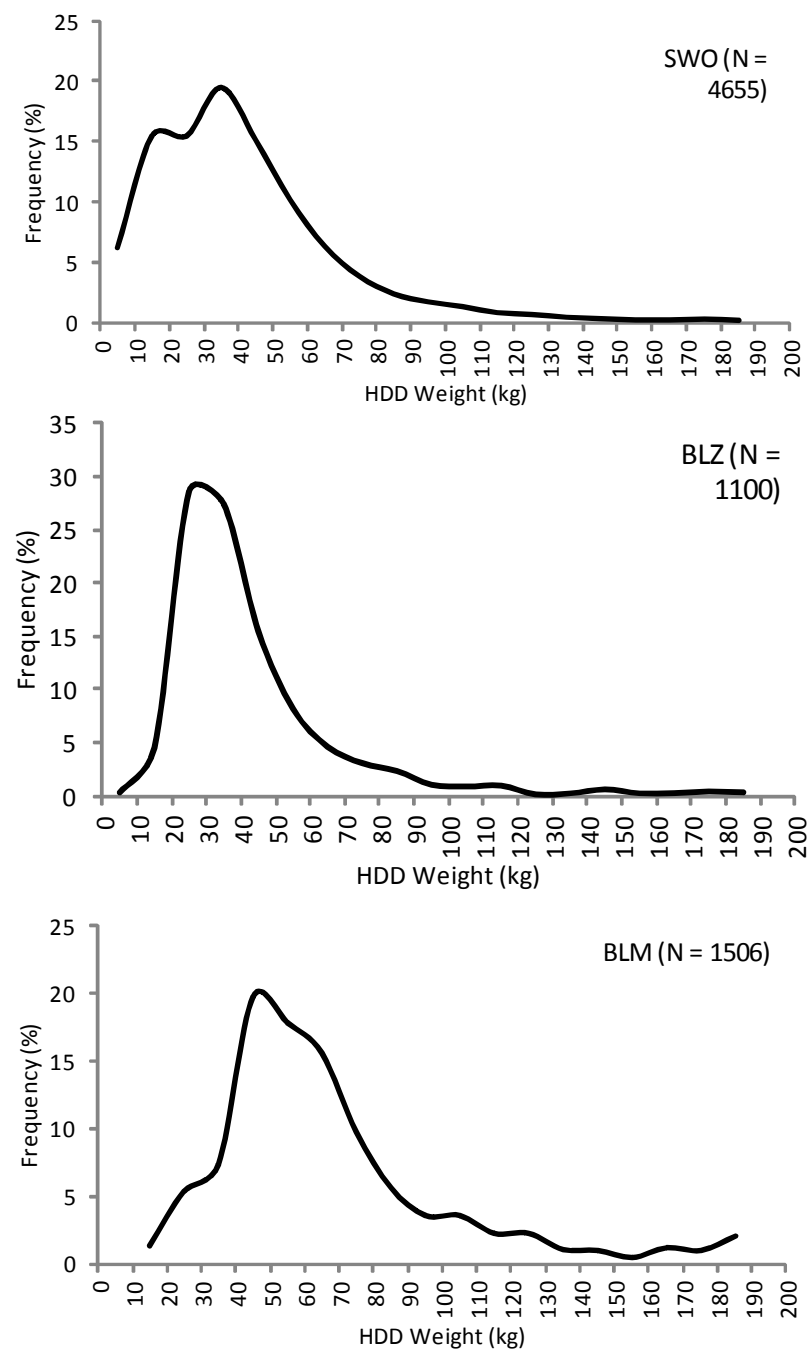
for striped marlin was $137.02 \mathrm{~cm}$ (PFL). Size at first capture (longline fisheries) of $T$. audax is approximately $80 \mathrm{~cm}$ eye-fork length (Nakamura, 1985). Size at first maturity generally estimated between 140 and $150 \mathrm{~cm}$ eye-fork length (Bromhead et al., 2004; Nakamura, 1985) while the others like sailfish and shortbill spearfish could not be estimated due to insufficient specimens.

Table 1. Parameters of length - weight relationship of dominant billfishes landed in Port of Benoa, February - December 2010.

\begin{tabular}{llccccc}
\hline No & Species & $\mathbf{n}$ & PFL Range $(\mathbf{c m})$ & Intercept (a) & Slope $(\mathbf{b})$ & $\mathbf{R}^{2}$ \\
\hline 1 & Xiphiasgladius & 284 & $68-210$ & 0.00003 & 2.9395 & 0.9298 \\
2 & Makaira indica & 120 & $108-332$ & 0.00008 & 2.6680 & 0.8602 \\
3 & Makaira mazara & 87 & $109-201$ & 0.00010 & 2.6181 & 0.6543 \\
4 & Tetrapturus audax & 42 & $95-165$ & 0.00020 & 2.5007 & 0.8947 \\
\hline
\end{tabular}

\section{CONCLUSION}

Based on billfishes landing data in Port of Benoa during February - December 2010, total 6 species were measured and the samples were dominated by swordfish (Xiphias gladius) $54.9 \%$, blue marlin (Makaira mazara) $17.8 \%$ and black marlin (Makaira indica) $13.0 \%$ respectively, followed by small amount of striped marlin, sailfish, and shortbil spearfish. Generally the individual size of billfishes range between $68-206 \mathrm{~cm}$ (PFL), and showing negative allometric pattern except for swordfish which was isometric. Most of billfishes landed haven't reached their first sexual maturity.

\section{ACKNOWLEDGEMENT}

The authors would like to thank to all enumerator members in Research Institute for Tuna Fisheries Benoa for their contribution in collecting data throughout the year.

\section{REFERENCES}

Asano-Filho, M., Holanda, F. C. A. F., Santos, F. J. D., Lucena, F. \& G. D. L. Pantaleão. 2004. A short note on the catch composition and weight-length relationship of tunas, billfishes and sharks of north Brazil. Brazilian Journal of Oceanography. 52 (3/ 4): 249-253.

Bromhead, D., Pepperell, J., Wise, B., \& J. Findlay. 2004. Striped marlin: biology and fisheries. Bureau of Rural Sciences. Canberra. p.15-37.

Campbell, R. A., G. N. Tuck, J. G. Pepperell and J.W.P. Larcombe. 1998. Synopsis on the billfish stocks and fisheries within the western AFZ and the Indian Ocean. Report to Western Tuna MAC, AFMA, Canberra. 123 pp.

Conamar. 2008. Bilfish: threatened resources in the eastern Pacific Ocean. 3 (4). Year 3. www.fconamar.org (downloaded on March $25^{\text {th }}$, 2011).

Froese, R. \& D. Pauly. 2011. FishBase. World wide web electronic publication. www.fishbase.org, version (02/2011).

Ganga, U., Pillai, N. G. K. \& M. N. K. Elayathu. 2008. Billfish fishery along the Indian coast with special reference to the Indo-Pacific sailfish Istiophorus platypterus (Shaw and Nodder 1792). J. Mar. Biol. Ass. India. 50 (2) : 166 - 171.

Hoolihan, J. P. 2006. Age and growth of Indo-Pacific sailfish, Istiophorus platypterus,from the Arabian Gulf. Fisheries Research. 78: 218-226.

IOTC. 2002. Field manual for data collection on tuna landings from longliners. IOTC Technical Report 02/02. $15 \mathrm{pp}$.

IOTC. 2005. Biological data on tuna and tuna-like species gathered at the IOTC Secretariat: Status Report. IOTC-2005-WPTT-05. 22 pp.

Mahiswara \& B. I. Prisantoso. 2009. Billfish fisheries in Indonesia. IOTC-2009-WPB-14. 10 pp.

Maldeniya, R., Dayaratne, P \& P.D.K.D. Amarasooriya. 1999. An analysis of billfish landings 
in the pelagic fisheries in Sri Lanka. IOTC proceedings. 2-5: 1999-2002.

Nakamura, I. 1985. FAO species catalogue. Vol. 5. Billfishes of the world. An annotated and illustrated catalogue of marlins,, sailfishes, spearfishes and swordfishes known to date. FAO Fish. Synop., 5 (125): 65.

Novianto, D., Nugraha, B. \& A. Bahtiar. 2010. Komposisi ukuran, perbandingan jenis kelamin, dan tingkat kematangan gonad ikan todak berparuh pendek (Tetrapturus angustirostris) di Samudera Hindia. BAWAL. 3 (2): $123-128$.

Pepperell, J.G. 2000. Brief synopsis of the biology of the black marlin (Makaira indica), with reference to the indian ocean. IOTC Proceedings. 3 (2000): 214-220.

Pepperell, J.G. \& P. Grewe. 1999. A field guide to the Indo-Pacific billfishes. CSIRO Marine Research, Hobart, TAS. 16 pp.

Poisson, F \& C. Fauvel. 2009. Reproductive dynamics of swordfish (Xiphias gladius) in the southwestern Indian Ocean (Reunion Island). Part 1: oocyte development, sexual maturity and spawning. Aquat. Living Resour. 22: 45-58.

Poisson, F \& M. Taquet. 2000. French swordfish Iongline fishery in south west Indian Ocean : preliminary results from the PPR program. IOTC Poceedings. 3 (2000): 169-20.

Sun, C. L., Wang, S. P \& S. Z. Yeh. 2002. Age and growth of the swordfish (Xiphias gladius L.) in the waters around Taiwan determined from anal-fin rays. Fish. Bull. 100: 822-835.
Sun, C.L., Wang, S.P., Porch, C.E, \& S.Z. Yeh. 2005. Sex-specific yield per recruit and spawning stock biomass per recruit for the swordfish, Xiphias gladius, in the waters around Taiwan. Fisheries Research $71: 61-69$.

Ueyanagi, S. \& P. G. Wares. 1975. Synopsis of biological data on striped marlin, Tetrapturus audax (Philippi), 1887. Richard S. Shomura and F. Williams (eds.) Proceedings of the international billfish symposium, Pt.3. U.S. Department of Commerce, NOAA Technical Report NMFS SSRF 675, p.132-159.

Vega, R., Licandeo, R., Rosson, G. \& E. Yáñez. 2009. Species catch composition, length structure and reproductive indices of swordfish (Xiphias gladius) at Easter Island zone. Lat. Am. J. Aquat. Res., 37 (1): 83-95.

Wang, S. P.,Sun, C.L. and Su-Zan Yeh. 2003. Sex ratios and sexual maturity of swordfish (Xiphias gladius L.) in the waters of Taiwan. Zoological Studies 42 (4): 529-539.

Wang, S. P., Sun, C.L., Yeh, S. Z., Chiang, W. C., Su, N. J., Chang, Y. J. \& C.H. Liu. 2006. Length distributions, weight-length relationships, and sex ratios at lengths for the billfishes in Taiwan Waters. BULLETIN OF MARINE SCIENCE, 79 (3): 865869.

Yabe, H., Ueayanagi, S., Kikawa, S. \& H. Watanabe. 1959. Study on the life-history of the swordfish, Xiphias gladius Linnaeus. Rep. Nankai Reg. Fish. Res. Lab. 10: 107-150. 